\title{
Herbicide Efficacy on Borreria densiflora Control in PRE- AND Post-Emergence Conditions ${ }^{1}$
}

\author{
Eficácia de Herbicidas no Controle de Borreria densiflora em Condições de Pré e \\ Pós-Emergência
}

MARTINS, B.A.B. ${ }^{2}$ and CHRISTOFFOLETI, P.J. ${ }^{3}$

\begin{abstract}
The weed Borreria densiflora is a management issue in soybean and sugarcane crops from North and Northeastern Brazil. Knowledge upon chemical control of B. densiflora contributes to the integrated management of this weed species, especially when active ingredient options become reduced due to the selection of herbicide resistant or tolerant weed species. Experiments in pre- and post-emergence of $B$. densiflora were conducted in greenhouse, in a randomized block design and four replications. In pre-emergence, the doseresponse curve methodology was used and 7 herbicides were tested. In post-emergence, 9 herbicides at the recommended rate and 4 herbicide mixtures were tested. For pre and post-emergence conditions, evaluations were conducted at 60 and 21 days after treatment (DAT), respectively, and the variables analyzed were weed control and dry weight (\%). The results showed options of pre-emergent herbicides that can be used for controlling $B$. densiflora, especially in sugarcane, where chemical weed control is mainly based on preemergent applications. In the current glyphosate resistance scenario, one should consider the use of pre-emergent herbicides within an integrated management of $B$. densiflora. For satisfactory post-emergence control, $B$. densiflora plants should be sprayed at the phenological stage of up to three pairs of leaves. Herbicide mixtures have been and will continue to be an important tool in chemical weed management, broadening the spectrum of weed control, while diversifying herbicide mechanisms of action, which helps to prevent or delay the appearance of herbicide resistance.
\end{abstract}

Keywords: vassourinha-de-botão, chemical control, dose-response, herbicide mixtures, integrated weed management.

RESUMO - A planta daninha Borreria densiflora é uma espécie de dificil manejo em soja e canade-açúcar no Norte e Nordeste do Brasil. O conhecimento do manejo quimico de B. densiflora contribui para o manejo integrado dessa espécie, sobretudo quando opções de ingredientes ativos se tornam reduzidas devido à seleção de plantas daninhas resistentes e tolerantes. Experimentos em pré e pós-emergência de B. densiflora foram instalados em casa de vegetação em blocos casualizados com quatro repetições. Em pré-emergência, a metodologia de curvas de dose-resposta foi utilizada e sete herbicidas foram testados. Em pós-emergência, nove herbicidas e quatro misturas destes foram testados. Em pré e pós-emergência, as avaliações foram feitas aos 60 e 21 dias após aplicação (DAA), respectivamente, e as variáveis avaliadas foram controle e massa seca (\%) de B. densiflora. Os resultados indicaram opções de herbicidas pré-emergentes que podem ser usados para controle de $\boldsymbol{B}$. densiflora, especialmente em cana-de-açúcar, em que o manejo químico de plantas daninhas baseia-se em aplicações pré-emergentes. Diante do fenômeno da resistência de plantas daninhas ao glyphosate, devem-se considerar os herbicidas pré-emergentes como uma ferramenta importante dentro de um programa de manejo integrado de B. densiflora. Para controle pós-emergente satisfatório, plantas dessa espécie devem ser tratadas no estádio fenológico de até três pares de folhas. As misturas de herbicidas têm sido e continuarão a ser uma importante ferramenta no controle quimico de plantas daninhas, aumentando o espectro de controle de plantas daninhas e diversificando os mecanismos de ação, o que ajuda a prevenir e retardar o aparecimento da resistência à herbicidas.

Palavras-chave: vassourinha-de-botão, controle químico, dose-resposta, mistura de herbicidas, manejo integrado de plantas daninhas.

Recebido para publicação em 17.9.2014 e aprovado em 16.10.2014.

2 Embrapa Milho e Sorgo, Sete Lagoas-MG, Brasil, <m.babmarti@gmail.com>; ${ }^{3}$ Escola Superior de Agricultura “Luiz de Queiroz”, Piracicaba-SP, Brasil 


\section{INTRODUCTION}

Weed management tactics are converging to the most sustainable manner possible, where cultural, mechanical and chemical control methods have been integrated within the production systems. Chemical control is the most predominant method in agricultural production systems worldwide (Zimdahl, 2013). Even before crop planting, mechanical soil operations have been widely replaced by herbicide applications in several cropping systems. The herbicides used in this preplanting chemical method are known as burndown herbicides, within no-tillage systems.

In Brazil, herbicides that are registered to be used in pre-planting burndown operations are: 2,4-D, diquat, glyphosate, MSMA, paraquat, glufosinate-ammonium (Melhorança, 2002). Herbicide tank mixes, including glyphosate + 2,4-D and carfentrazone-ethyl + glyphosate, are also used by growers for burndown operations. Among the burndown herbicides, paraquat and glyphosate are the most used, and therefore, subjected to several efficacy evaluation studies (Voll, 1987). The tank mixture of 2,4-D and glyphosate results in greater broadleaf activity, without losing the graminicide activity of glyphosate (Koch et al., 1989; Oliveira Jr., 2001). Herbicide efficacy depends on several factors, including physico-chemical characteristics and dose of the product, the weed species to be controlled and the phenological stage of weed and crop (Christoffoleti \& López-Ovejero, 2004).

The weed $B$. densiflora is reported to be a difficult-to-control weed species, especially with burndown herbicide applications in no-tillage fields, where it has been reported as occurring in large infestations in soybean and sugarcane production areas in North and Northeastem Brazil. This weed is a simple perennial species within the Rubiaceae family and belongs to the genus Borreria G. Mey. Thermal amplitudes, temperatures above $25{ }^{\circ} \mathrm{C}$, presence of light and capacity of regrowth after cutting influence the population dynamics of $B$. densiflora (Martins et al., 2009, 2010).

The present study had the objective to evaluate the efficacy of some herbicides and herbicide mixtures recommended for pre and post-emergence management, as well as in burndown applications, on the control of B. densiflora.

\section{MATERIAL AND METHODS}

Pre-emergence - Seeds were collected in 2007 from soybean production fields infested with $B$. densiflora, in North Tocantins State

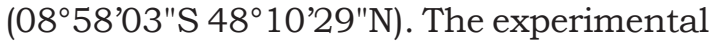
design used was the randomized block design, with four replications, under an $8 \times 7$ factorial arrangement. The herbicides tested were chosen based on their representativeness in pre-emergent applications in soybean and sugarcane (Table 1). Eight doses of each herbicide tested were used (1/16D, 1/8D, 1/4D, $1 / 2 \mathrm{D}, 1 \mathrm{D}, 2 \mathrm{D}, 4 \mathrm{D}$ and $0 \mathrm{D})$. $\mathrm{D}$ is the recommended dose in the label of each herbicide (Table 1), and the experiment comprised 224 experimental units.

A 3L plastic pot represented each experimental unit, which contained clay soil $(46,5 \%$ of clay, $14,5 \%$ of silt e $39 \%$ of sand) and 40 seeds of $B$. densiflora. Proportional fertilization of $37,5 \mathrm{~kg} \mathrm{ha}^{-1}$ of nitrogen, $37,5 \mathrm{~kg} \mathrm{ha}^{-1}$ of phosphorus and $50 \mathrm{~kg} \mathrm{ha}^{-1}$ of potassium was provided to all pots containing the seeds. The chemical properties of the soil used in the pre-emergence experiment are presented in Table 2.

Herbicide spraying was done using a XR80.02, even, flat-fan nozzle and an overhead, compressed-air sprayer, calibrated to deliver $216 \mathrm{~L} \mathrm{ha}^{-1}$, working at a pressure of 2.5 bar. Following herbicide spraying, all pots received a water lamina proportional to a $10 \mathrm{~mm}$ precipitation. Irrigation was provided as necessary.

Post-emergence - Seeds of B. densiflora were germinated in germination chamber under $20 / 30{ }^{\circ} \mathrm{C}$ day/night temperatures with a 12-hour photoperiod (Martins et al., 2010). The seedlings were transplanted to $1.5 \mathrm{~L}$ plastic pots. Ten days after transplanting, the seedlings were thinned to one plant per pot. The pots were filled with commercial potting mix (Plantmax ${ }^{\circledR}$ ) and fertilized with $4 \mathrm{~g}$ of the granulated commercial formula 10-10-10 and $0.1 \mathrm{~g}$ of Ouro Verde $^{\circledR}$ commercial liquid fertilizer diluted in $50 \mathrm{~mL}$ of water. 
At the 3 pairs of leaves stage, treatments were applied at the recommended rate of each herbicide (Table 3). Herbicide spraying was done using a XR110.02, even, flat-fan nozzle and an overhead, compressed-air sprayer, calibrated to deliver $195 \mathrm{~L} \mathrm{ha}^{-1}$, working at a pressure of 2 bar.

For both pre-emergence and postemergence experiments, control was visually recorded, at 60 and 28 DAT respectively, ranging from $0 \%$ (lack of control) to $100 \%$ (absolute control), according to the scale developed by the Latin America Weed Association (ALAM, 1974). Shoot biomass was collected, stored in paper bags and kept in air flow chamber at $70{ }^{\circ} \mathrm{C}$ for 48 hours. Dry biomass data are expressed as percentages of the untreated control.

Table 1 - Pre-emergent herbicide treatments at the recommended rate (1D)

\begin{tabular}{|c|c|c|c|}
\hline \multicolumn{2}{|c|}{ Treatment } & \multicolumn{2}{|c|}{ Rate } \\
\hline Commercial product (c.p.) & Active ingredient (a.i.) & $\left(\mathrm{mL}\right.$ or g p.c. $\left.\mathrm{ha}^{-1}\right)$ & $\left(\right.$ g a.i. ha $\left.{ }^{-1}\right)$ \\
\hline \multicolumn{2}{|c|}{ Untreated Control } & -- & -- \\
\hline Gamit & clomazone & 2,500 & 1,250 \\
\hline Spider $840 \mathrm{WG}$ & diclosulan & 41.7 & 35.02 \\
\hline Dual Gold & S-metolachlor & 2,000 & 1,920 \\
\hline Sencor 480 & metribuzin & 1,000 & 480 \\
\hline Herbadox $500 \mathrm{CE}$ & pendimethalin & 3,000 & 1,500 \\
\hline Scepter & imazaquin & 1,100 & 165 \\
\hline Boral $500 \mathrm{SC}$ & sulfentrazone & 1,200 & 600 \\
\hline
\end{tabular}

Table 2 - Chemical properties of the soil used in the pre-emergence experiment

\begin{tabular}{|c|c|c|c|c|c|c|c|c|c|c|c|}
\hline M.O. & P resin & $\mathrm{K}$ & $\mathrm{Ca}$ & $\mathrm{Mg}$ & $\mathrm{H}+\mathrm{Al}$ & $\mathrm{Al}$ & $\mathrm{SB}$ & $\mathrm{CTC}$ & $\mathrm{V}$ & $\mathrm{m}$ \\
\hline$\left(\mathrm{g} \mathrm{dm}^{-3}\right)$ & $\left(\mathrm{mg} \mathrm{dm}^{-3}\right)$ & \multicolumn{6}{|c|}{$\left(\mathrm{mmol}_{\mathrm{c}} \mathrm{dm}^{-3}\right)$} & \multicolumn{3}{|c|}{$(\%)$} \\
\hline 8 & 1 & 0,3 & 36 & 11 & 15 & 0 & 47 & 62 & 76 & 0 \\
\hline
\end{tabular}

Table 3 - Post-emergent herbicide treatments at the recommended rate

\begin{tabular}{|c|c|c|c|}
\hline \multirow{2}{*}{ Commercial product (c.p.) } & \multirow{2}{*}{ Active Ingredient (a.i.) } & \multicolumn{2}{|c|}{ Rate } \\
\hline & & (mL or g c.p. ha $^{-1}$ ) & $\left(\mathrm{g}\right.$ a.i. $\left.\mathrm{ha}^{-1}\right)$ \\
\hline \multicolumn{2}{|c|}{ Untreated Control } & -- & -- \\
\hline Cobra & lactofen & 500 & 120 \\
\hline Flex & fomesafen & 600 & 150 \\
\hline Pivot & imazethapyr & 700 & 74.2 \\
\hline Classic & chlorimuron-ethyl & 50 & 12.5 \\
\hline Pivot + Cobra & imazethapyr + lactofen & $600+300$ & $60+72$ \\
\hline Pivot + Classic & imazethapyr + chlorimuron-ethyl & $600+0.04$ & $60+10$ \\
\hline Pivot + Classic + Cobra & imazethapyr + chlorimuron + lactofen & $600+0.04+300$ & $60+10+72$ \\
\hline MSMA San. 720 SL & MSMA & 4,000 & 2,880 \\
\hline DMA 806 & $2,4-\mathrm{D}$ & 1,000 & 670 \\
\hline Roundup WG & glyphosate & 1,500 & 1,080 \\
\hline Roundup WG + DMA 806 & glyphosate $+2,4-\mathrm{D}$ & $1,500+1,000$ & $1,080+670$ \\
\hline Aurora + Roundup WG & carfentrazone-ethyl + glyphosate & $32+1,500$ & $12.8+1,080$ \\
\hline Gramoxone & paraquat & 2,000 & 400 \\
\hline
\end{tabular}


Statistical Analysis - For the dose-response experiment in pre-emergence, herbicide was considered as a factor, and the doses represented the levels of the factor. Control (\%) data were adjusted to a hyperbolic model of 2-parameters, $a$ and $b$, as follows:

$$
y=\frac{\left(a^{*} b\right)}{(b+x)}
$$

where $y$ is $B$. densiflora control (\%), $a$ and $b$ are the slope and asymptote of the hyperbolic curve, respectively, and $x$ is the herbicide rate. Significance of factorial interactions was analyzed (herbicide*dose) using the least square means test with Tukey adjustment for multiple comparisons via the PROC GLM statement in SAS (version 9.3, SAS Institute, Cary, NC). For the post-emergence experiment with a single dose for each herbicide tested, data were subjected to ANOVA to test significant differences among herbicides for control and dry biomass (\%) using ANOVA with the PROC GLM statement in SAS (version 9.3, SAS Institute, Cary, NC).

\section{RESULTS AND DISCUSSION}

For the experiment in pre-emergence, a significant interaction between herbicide and dose was detected $(\mathrm{p}<0.0001)$, and control data were fit to a hyperbolic regression (Figure 1, Tables 4 and 5). Studies have been reported using hyperbolic regressions for building doseresponse curves to other weed species (Bósnic \& Swanton, 1997; Monquero, 1999; Knezevic et al., 2009).

All herbicides, except clomazone, controlled $B$. densiflora since the lowest rate, indicating the high susceptibility of this species to these herbicides (Figure 1). There was no difference in control or dry biomass (\%) among the herbicides tested, except clomazone. We decided to test clomazone because despite of being recommended to control grass species, clomazone has activity on some broadleaf weeds. Borreria densiflora control with clomazone at the field rate was not satisfactory and was lower compared to the other herbicides tested (Table 5).

The organic matter content in the soil is the first factor that influences the sorption of many herbicides, including metribuzin (Harper, 1994). Control and dry biomass (\%) at 60 DAT for metribuzin were $100 \%$ and $0 \%$, respectively, since the lowest rate. Thus, plots for metribuzin were not included in Figure 1. Organic matter increases microbial activity, increasing the speed with which herbicides are degraded in the soil, resulting in reduced persistence (Prata \& Lavorenti, 2000). The low organic matter content in the soil used in this experiment might have contributed to the availability and persistence of the preemergent herbicides tested, even in low rates, except clomazone, until 60 DAT.

Diclosulam controlled $B$. densiflora since $1 / 4$ of its recommended rate. This herbicide possesses great efficacy in broadleaf weed species such as Spermacoce latifolia, in the Rubiaceae family, with which $B$. densiflora share similar characteristics. Imazaquin provided satisfactory control of $B$. densiflora with the recommended rate (Table 5). This herbicide was widely used in soybean as an alternative to metribuzin tolerant weed species. Despite that, in the mid 1990's, imazaquin resistant weed species were selected after several years of repetitive use of this herbicide. These species include Euphorbia heterophylla and Bidens pilosa and tolerant species were also selected, such as the weed Cardiospermum halicacabum (Vargas \& Gazziero, 2014).

Pre-emergent herbicides, including metribuzin and imazaquin, and selective post-emergent, herbicides were gradually replaced by glyphosate after the glyphosate resistant soybean was launched. The repetitive use of glyphosate lead to the selection of resistant and/or tolerant weed biotypes to this herbicide. As examples, B. latifolia is known to be tolerant to glyphosate (Gazziero \& Prette, 2005; Maciel et al., 2009), and woody borreria (B. verticillata syn. Hedyotis verticillata) was found to be resistant to both paraquat and glyphosate in oil palm plantations from Malaysia (Chuah et al., 2005). Therefore, the pre-emergent herbicides tested in this study represent options to be included in the integrated management of not only species within the Borreria genus, but also other weed species in glyphosate resistant soybean, which was estimated to be $90 \%$ of the planted 

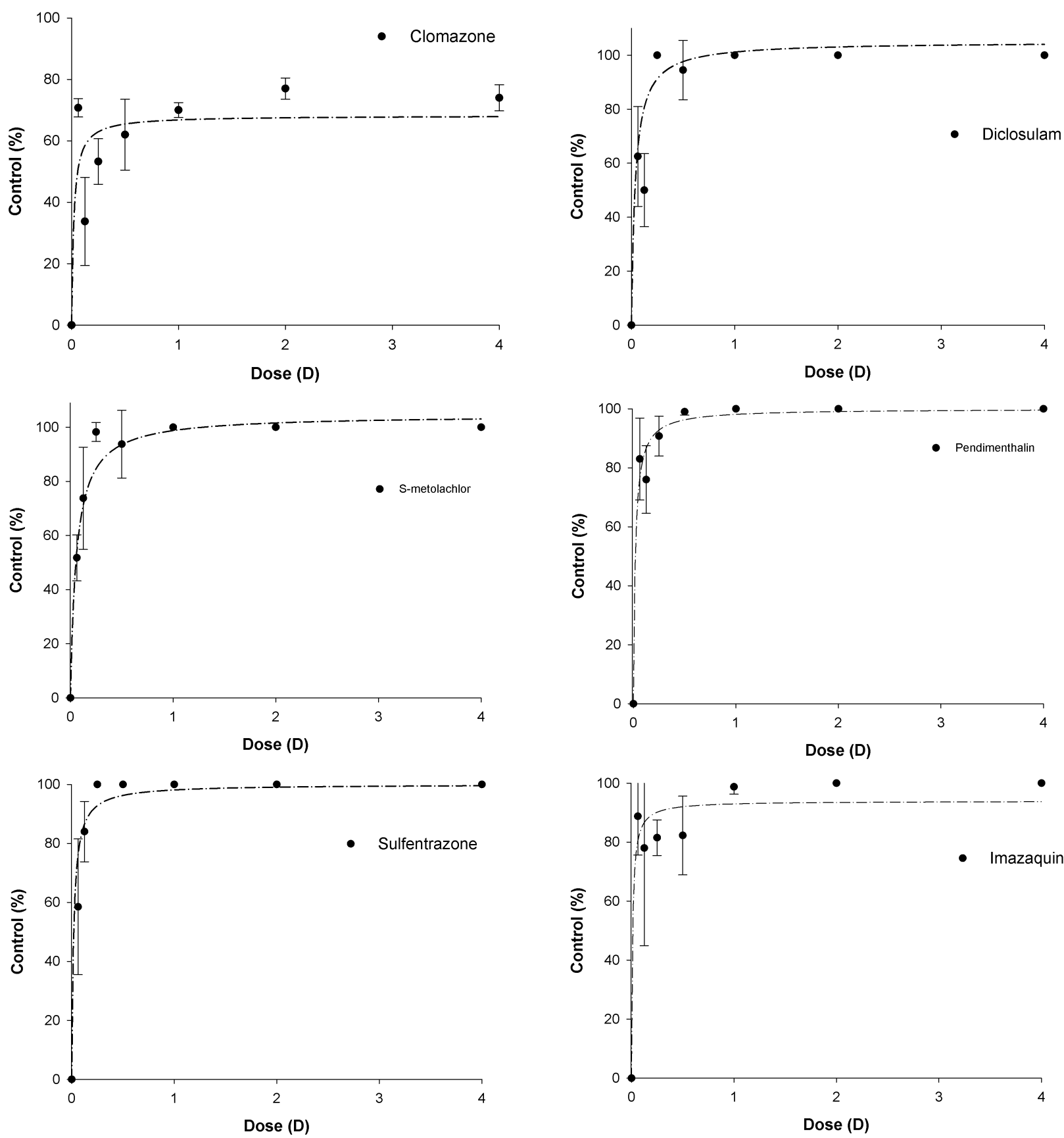

Figure 1 - Control (\%) of $B$. densiflora at 60 DAT as a function of pre-emergent herbicide dose. Dose 1 represents the herbicide recommended rate (1D).

soybean area in Brazil in the 2012/2013 season (Gomes \& Borém, 2013). Moreover, several weed species, including those from the Borreria genus, possess ecological plasticity throughout Brazil and are on the list of species likely to develop resistance to herbicides used in cultivation, being the soybean crop genetically modified or not (Vivian et al., 2013).
It is necessary to avoid the continuous use of herbicides with the same mechanism of action in the same area, favoring the rotation of mechanisms of action in order to collaborate with the reduction of selection pressure upon the agroecossystem (Christoffoleti et al., 1994). Understanding herbicide efficacy on weed species over time is important because 
Table 4 - Estimates of parameters a and $\mathrm{b}$ and determination coefficients $\left(\mathrm{r}^{2}\right)$ and parameter probabilities $(\mathrm{p})$ of the hyperbolic model for the response variable control (\%), at $60 \mathrm{DAT}^{1}$

\begin{tabular}{|c|c|c|c|c|}
\hline \multirow{2}{*}{ Herbicide } & \multicolumn{2}{|c|}{ Parameter } & \multirow{2}{*}{$\mathrm{r}^{2}$} & \multirow{2}{*}{$\mathrm{p}$ (model) } \\
\cline { 2 - 3 } & $\mathrm{a}$ & $\mathrm{b}$ & & \\
\hline Clomazone & 68.1610 & 0.0207 & \multirow{2}{*}{0.71} & $<0.0001$ \\
\hline $\mathrm{p}$ & $<0.001$ & 0.05 & & \\
\hline Diclosulan & 104.5696 & 0.0588 & \multirow{2}{*}{0.90} & $<0.0001$ \\
\hline $\mathrm{p}$ & $<0.0001$ & $<0.0001$ & & \\
\hline S-metolachlor & 104.7782 & 0.0518 & \multirow{2}{*}{0.93} & $<0.0001$ \\
\hline $\mathrm{p}$ & $<0.0001$ & $<0.0001$ & & \\
\hline Pendimethalin & 100.0205 & 0.0195 & \multirow{2}{*}{0.95} & $<0.0001$ \\
\hline $\mathrm{p}$ & $<0.0001$ & $<0.0001$ & & \\
\hline Sulfentrazone & 105.0040 & 0.0378 & \multirow{2}{*}{0.93} & $<0.0001$ \\
\hline $\mathrm{p}$ & $<0.0001$ & $<0.0001$ & & \\
\hline Imazaquin & 93.9178 & 0.0105 & \multirow{2}{*}{0.82} & $<0.0001$ \\
\hline $\mathrm{p}$ & $<0.0001$ & 0.05 & & \\
\hline
\end{tabular}

1/ Model: $y=a^{*} x /(b+x)$.

Table 5 - Pre-emergent control (\%) of B. densiflora, 60 DAT

\begin{tabular}{|l|c|c|}
\hline \multirow{2}{*}{ Herbicide } & \multicolumn{2}{|c|}{ Control (\%) } \\
\cline { 2 - 3 } & Comercial dose & $\begin{array}{c}\text { Half of } \\
\text { commercial dose }\end{array}$ \\
\hline Untreated control & $0 \mathrm{c}$ & $0 \mathrm{c}$ \\
\hline Clomazone & $80 \mathrm{~b}$ & $70 \mathrm{~b}$ \\
\hline Diclosulan & $100 \mathrm{a}$ & $100 \mathrm{a}$ \\
\hline Pendimethalin & $100 \mathrm{a}$ & $100 \mathrm{a}$ \\
\hline S-metolachlor & $100 \mathrm{a}$ & $100 \mathrm{a}$ \\
\hline Metribuzin & $100 \mathrm{a}$ & $100 \mathrm{a}$ \\
\hline Sulfentrazone & $100 \mathrm{a}$ & $100 \mathrm{a}$ \\
\hline Imazaquin & $100 \mathrm{a}$ & $100 \mathrm{a}$ \\
\hline
\end{tabular}

Means followed by the same letters, in columns, do not differ at $\mathrm{p}=0.005$.

knowledge about this characteristic helps when choosing herbicide rates to obtain the desired residual effect, in case of chemical management in pre-emergence (Carvalho et al., 2005) - especially in sugarcane, given that it is the main weed management tactic used. In pre-planting operations, pre-emergent herbicides can also be mixed with postemergence herbicides, aiming residual weed control. Thus, it is important to know the physico-chemical characteristics of each herbicide formulation to be mixed, as well as the cropping system, e.g., if tillage has been adopted or if the land is under no-tillage.
According to the germination dynamics of B. densiflora (Martins et al., 2010), the preemergent herbicides tested in this study, except clomazone, showed the necessary residual period for controlling this weed species.

For the experiment in post-emergence, the $F$ value was significant for control and dry biomass, at $5 \%$ of probability $(p<0,001)$. The herbicide MSMA had an inferior control of $B$. densiflora compared to the other herbicides tested (Table 6). At 21 DAT, B. densiflora control was $78.5 \%$ with MSMA. Borreria densiflora dry biomass (\%) from all herbicide treatments was lower than that from MSMA (Table 7).

All the other herbicides tested controlled $B$. densiflora at the recommended rate, despite differences have been detected (Table 6). The control achieved with glyphosate was lower compared with all herbicide mixtures and herbicides lactofen and chlorimuron-ethyl alone. All herbicide mixtures tested provided control of $B$. densiflora above 97\% (Table 6).

The mixture of glyphosate with other herbicides possessing different mechanisms of action is recommended for the prevention and control of glyphosate tolerant weed species in areas intensively treated with this herbicide, in which a reduced amount of each herbicide is used in the tank mixture (Kruse et al., 2000; Gazziero \& Prette, 2005). The susceptible and resistant weed biotypes are controlled by the herbicide mixture, that is, the resistant biotype to one of the active ingredients is controlled by the other added in the mixture (Powles \& Holtum, 1994).

In a study with Spermacoce latifolia and Richardia braziliensis, the mixture of glyphosate with other herbicides provided control above $95 \%$, compared to $85 \%$ when glyphosate was applied alone (Ferreira et al., 2006). In the present study, a similar pattern was observed (Table 6).

The mixture of active ingredients has the objective to enhance weed control in comparison to the use of the same ingredients alone. When the control obtained with the mixture is greater than the expected control with the herbicides alone, such mixture is called sinergistic; when the control is less than 
Table 6 - Post-emergence control (\%) of B. densiflora, 21 DAT

\begin{tabular}{|l|c|}
\hline \multicolumn{1}{|c|}{ Treatment } & Control (\%) \\
\hline Untreated control & $0.0 \mathrm{~d}$ \\
\hline Glyphosate + 2,4-D & $100.0 \mathrm{a}$ \\
\hline Paraquat & $94.5 \mathrm{ab}$ \\
\hline Lactofen & $100.0 \mathrm{a}$ \\
\hline Fomesafen & $90.0 \mathrm{ab}$ \\
\hline Chlorimuron-ethyl & $98.7 \mathrm{a}$ \\
\hline Imazethapyr & $95.0 \mathrm{ab}$ \\
\hline Glyphosate & $87.5 \mathrm{~b}$ \\
\hline Imazethapyr + lactofen & $100.0 \mathrm{a}$ \\
\hline Carfentrazone-ethyl + glyphosate & $100.0 \mathrm{a}$ \\
\hline Imazethapyr + chlorimuron-ethyl & $97.5 \mathrm{a}$ \\
\hline Imazethapyr + chlorimuron-ethyl + lactofen & $100.0 \mathrm{a}$ \\
\hline MSMA & $76.5 \mathrm{c}$ \\
\hline VC $(5 \%)^{1 /}=4.96$ & $\mathrm{~F}_{\text {(treatments) }}=124.13^{-}$ \\
\hline
\end{tabular}

${ }^{1 /} \mathrm{VC}$, variation coefficient at $\mathrm{p}=0.005$. Means followed by the same letters, in columns, do not differ at $\mathrm{p}=0.005$. ${ }^{*} \mathrm{~F}$ significant at $\mathrm{p}=0.05$.

Table 7 - Residual dry biomass (\%) of B. densiflora, 21 DAT

\begin{tabular}{|c|c|}
\hline Treatment & $\begin{array}{l}\text { Residual dry } \\
\text { biomass (\%) }\end{array}$ \\
\hline Untreated control & $100.00 \mathrm{a}$ \\
\hline Glyphosate+2,4-D & $3.52 \mathrm{bc}$ \\
\hline Paraquat & $5.30 \mathrm{bc}$ \\
\hline Lactofen & $1.21 \mathrm{c}$ \\
\hline Fomesafen & $10.34 \mathrm{bc}$ \\
\hline Chlorimuron-ethyl & $8.17 \mathrm{bc}$ \\
\hline Imazethapyr & $12.86 \mathrm{~b}$ \\
\hline Glyphosate & $7.69 \mathrm{bc}$ \\
\hline Imazethapyr + lactofen & $4.74 \mathrm{bc}$ \\
\hline Carfentrazone-ethyl + glyphosate & $3.83 \mathrm{bc}$ \\
\hline Imazethapyr + chlorimuron-ethyl & $4.52 \mathrm{bc}$ \\
\hline Imazethapyr + chlorimuron-ethyl + lactofen & $4.88 \mathrm{bc}$ \\
\hline MSMA & $27.65 \mathrm{ab}$ \\
\hline $\operatorname{VC}(5 \%)^{1 /}=49.8$ & $\mathrm{~F}_{\text {(treatments) }}=5.16$ \\
\hline
\end{tabular}

${ }^{1 /} \mathrm{VC}$, variation coefficient at $\mathrm{p}=0.005$. Means followed by the same letters, in columns, do not differ at $\mathrm{p}=0.005$. ${ }^{*} \mathrm{~F}$ significant at $\mathrm{p}=0.05$.

the expected, the herbicide mixture is antagonistic and when control is the same between the mixture and the herbicides alone, it is called additive (Colby, 1967). Results of the present study suggest a sinergistic effect of the herbicide mixtures on the control of $B$. densiflora (Table 6). However, further analyses are necessary to classify the conjoint effect of the active ingredients in the mixtures tested. Knowing both site and mode of action of the compounds in a mixture provides the biological basis for choosing the appropriate reference model to assess the effects of these compounds in the mixture (Streibig, 2003).
Due to the great weed species diversity in the region under vegetation of cerrado, where $B$. densiflora has been a management issue, the combination of glyphosate with other herbicides have been used, in order to maximize its control, while increasing the number of weed species controlled. It is important to recognize that glyphosate can be combined not only with some post-emergence herbicides used in conventional soybean, but also with some herbicides that have pre-emergence activity.

Borreria densiflora becomes increasingly tolerant to post-emergence herbicides during its development. In a study, when $B$. densiflora was at the phenological stage of 4-5 pairs of leaves, lack of control was observed by some herbicides at the recommended rate, including imazethapyr, chlorimuron-ethyl, fomesafen and glyphosate (data not shown). Thus, herbicide dose appears to be correlated with phenological stage for the control of $B$. densiflora. The presence of lateral buds along the main stem nodes makes the herbicide contact with the lower leaves difficult, which allows survivor of the plant even after herbicide spraying. Thus, $B$. densiflora control becomes challenging after the phenological stage of 3 pairs of leaves, even using systemic herbicides.

Borreria densiflora is a difficult-to-control weed species in soybean pre-planting burndown, causing growers to use high glyphosate rates to obtain satisfactory control. Therefore, within the chemical management of $B$. densiflora in post-emergence, herbicide application should be done until the 3 pairs of leaves phenological stage because once the plant produces more leaves and lateral buds, its control becomes poor. This information is important, given that glyphosate, a postemergence herbicide, is one of the most used herbicides in soybean in Brazil (Meyer \& Cederberg, 2010), both in pre-planting burndown and post-emergence applications in glyphosate resistant soybeans.

All pre-emergent herbicides tested, except clomazone, are options to control B. densiflora, especially in sugarcane production areas, to which chemical weed control is based predominantly on pre-emergent applications. In the current context of glyphosate resistant 
weeds in the agricultural areas in Brazil and worldwide, it is important to recognize the use of pre-emergent herbicides as an important tool within integrated weed management programs. All post-emergent herbicides, except MSMA, provided satisfactory control of $B$. densiflora, when the herbicides were applied at the phenological stage of 3 pairs of leaves. It is recommended that post-emergence applications of $B$. densiflora be done until the growth stage of 3 pairs of leaves. The use of higher rates than the recommended in burndown operations to control $B$. densiflora should not be encouraged. It is important to follow the recommended rates in herbicide applications within each production system, as well as knowing the most appropriate time of spraying. Adoption of herbicide tank mixtures, although not allowed in official recommendations in Brazil, has been and still is an important operation to increase the spectrum of weed control within a chemical management, while saving costs of application, and slowing down the selection pressure of herbicide resistant and/or tolerant weeds.

\section{LITERATURE CITED}

ASOCIACION LATINOAMERICANA DE MALEZAS ALAM. Recomendaciones sobre unificación de los sistemas de evaluación em ensayos de control de malezas. ALAM, v. 1, n. 1, p. $35-38,1974$.

BÓSNIC, A. C.; SWANTON, C. J. Economic decision rules for postemergence herbicide control of barnyardgrass (Echinochloa crus-galli) in corn (Zea mays). Weed Sci., v. 45, n. 4, p. 557-563, 1997.

CARVALHO, S. J. P. et al. Curvas de dose-resposta para avaliação do controle de fluxos de emergência de plantas daninhas pelo herbicida imazapic. Planta Daninha, v. 23, n. 3, p. 535-542, 2005.

CHRISTOFFOLETI, P. J.; VICTORIA FILHO, R.; SILVA, C. B. Resistência de plantas daninhas aos herbicidas.

Planta Daninha, v. 12, n. 1, p. 13-20, 1994.

CHRISTOFFOLETI, P. J.; LÓPEZ-OVEJERO, R. F. Definições e situação da resistência de plantas daninhas aos herbicidas no Brasil e no Mundo. In: CHRISTOFFOLETI, P. J. (Coord.). Aspectos de resistência de plantas daninhas a herbicidas. 2.ed. Campinas: Associação Brasileira de Ação a Resistência de Plantas aos Herbicidas (HRAC-BR), 2004. p. 3-22.

Planta Daninha, Viçosa-MG, v. 32, n. 4, p. 817-825, 2014
CHUAH, T. S. et al. Paraquat and glyphosate resistance in woody borreria (Hedyotis verticillata) growing at oil palm plantations in Terengganu, Malaysia. Malaysia Appl. Biol., v. 34, n. 2, p. 43-49, 2005.

COLBY, S. R. Calculating synergistic and antagonistic responses of herbicide combinations. Weeds, v. 15, n. 1, p. 20-22, 1967.

FERREIRA, A. C. B.; BARROS, A. C.; LARNAS, F. M. Manejo de plantas daninhas na cultura do algodoeiro. Campina Grande: Embrapa, 2006. (Circular Técnica, 96)

GAZZIERO, D.; PRETTE, C. E. C. Resistência é a questão. R. Cultivar, v. 4, n. 1, p. 16-18, 2005.

GOMES, W. S.; BORÉM, A. biotecnologia: novo paradigma do agronegócio brasileiro. R. Econ. Agron., v. 11, n. 1, p. $115-136,2013$.

HARPER, S. S. Sorption-desorption and herbicide behavior in soil. Rev. Weed Sci., v. 6, p. 207-225, 1994.

KNEZEVIC, S. Z. et al. Dose-response curves of Kih-485 for preemergence weed control in corn. Weed Technol., v. 23, n. 1, p. 34-39, 2009.

$\mathrm{KOCH}, \mathrm{D}$. W. et al. Herbicides and adjuvants for sod control prior to no-till seeding of alfalfa. In: ANNUAL MEETING OF WESTERN SOCIETY OF WEED SCIENCE, v. 42, Honolulu, HI, 1989. Proceedings... Logan, UT, 1989. p. 29-32.

KRUSE, N. D.; TRESSI, M. M.; VIDAL, R. A. Herbicidas inibidores da EPSPs: revisão de literatura. R. Bras. Herbic., v. 1, n. 2, p. 139-146, 2000.

MACIEL, C. D. G. et al. Seletividade de cultivares de soja $\mathrm{RR}^{\circledR}$ submetidos a misturas em tanque de glyphosate + chlorimuron-ethyl associadas a óleo mineral e inseticidas. Planta Daninha, v. 27, n. 4, p. 755-768, 2009.

MARTINS, B. A. B. et al. A new variety of the weed Borreria densiflora DC. (Rubiaceae). Weed Biol. Manag., v. 9, n. 4, p. 286-291, 2009.

MARTINS, B. A. B. et al. Germinação de Borreria densiflora var. latifolia sob condições controladas de luz e temperatura. Planta Daninha, v. 28, n. 2, p. 301-307, 2010.

MEYER, D.; CEDERBERG, C. Pesticide use and glyphosate-resistant weeds - a case study of Brazilian soybean production. 2010. p. 5-6. (SIK-Rapport Nr 809)

MONQUERO, P. A. Biologia, manejo e caracterização bioquímica e genética de biótipos de plantas daninhas resistentes aos herbicidas inibidores da acetolactato sintase (ALS). 1999. 94 f. Dissertação (Mestrado em Fitotecnia) - Escola Superior de Agricultura "Luiz de Queiroz", Piracicaba, 1999. 
MELHORANÇA, A. L. Tecnologia de dessecação de plantas daninhas no sistema plantio direto. Dourados: 2002. 3 p. (Circular Técnica, 10)

OLIVEIRA JR., R. S. Seletividade de herbicidas para culturas e plantas daninhas. In: OLIVEIRA JR., R. S.;

CONSTANTIN, J. Plantas daninhas e seu manejo. Guaíba: Agropecuária, 2001.p. 291-314.

POWLES, S.; HOLTUM, J. Herbicide resistance in plants: biology and biochemistry. New York: CRC Press, 1994. $353 \mathrm{p}$.

PRATA, F.; LAVORENTI, A. Comportamento de herbicidas no solo: influência da matéria orgânica. Revista de Biociências, Taubaté, v. 6, n. 2, p. 17-22, 2000.

STREIBIG, J. C. Assessment of herbicide effects. $<$ http:// www.ewrs.org/et/images/Herbicide_interaction.pdf/. 2003>. Accessed on: Apr. 25th 2014.
VARGAS, L.; GAZZIERO, D. Seleção de plantas daninhas tolerantes e resistentes ao glyphosate. Disponível em: <http://www.agrolink.com.br/downloads/ GlifosatoeselecaoespeciesCongressomilho.PDF $>$. Acesso em: 12 maio 2014.

VIVIAN, R. et al. Weed management in soybean - issues and practices, soybean - Pest resistance. ISBN: 978-95351-0978-5, InTech, DOI: 10.5772/54595. Available from: $<$ http://www.intechopen.com/books/soybean-pest-resistance/ weed-management-in-soybean-issues-and-practices $>$. Accessed on: Apr. 25 2013.

VOLL, E. Efeitos do manejo da resteva do trigo, do preparo do solo e de herbicidas no controle de plantas daninhas na cultura da soja (Glycine max). $158 \mathrm{f}$. Tese (Doutorado em Cpg Em Solos e Nutrição de Plantas) - Escola Superior de Agricultura “Luiz de Queiroz", Universidade de São Paulo, Piracicaba, 1987.

ZIMDAHL, R. Fundamentals of weed science. New York: Academic Press, 2013. 666 p. 